\title{
Response of Citrus rootstocks to iron deficiency under high $\mathrm{pH}$ conditions
}

\author{
Meral Incesu ${ }^{1}$, Turgut Yesiloglu ${ }^{1}$, Onder Tuzcu ${ }^{1}$, Berken $_{\text {Cimen }}{ }^{1} \&$ Bilge Yilmaz $^{1}$
}

\begin{abstract}
SUMMARY
Turkey is one of the major citrus producing countries in the Mediterranean Basin. Approximately $90 \%$ of the total citrus production in Turkey is carried out in the Mediterranean Region. Soil of the Mediterranean region is calcareous and because sour orange is tolerant to high $\mathrm{pH}$, the rootstocks is widely used in this region. Sour orange rootstock, which is well adapted to calcareous soils, has positive effects on yield and quality, but is extremely sensitive to Citrus Tristeza Virus disease. Because sour orange is very sensitive to tristeza, there is a need to find an alternative rootstock that is well adapted to calcareous soils and has good fruit yield and quality. For this purpose, 16 citrus rootstock and genotypes could be used as a rootstock, were tested against high-pH conditions for iron chlorosis in growth chamber. At the end of this experiment, Tuzcu 891 sour orange, Gou Tou sour orange and Antalya Cleopatra mandarin were the most tolerant; Duncan grapefruit, Tuzcu 31-31 sour orange, Sunki mandarin, Nasnaran mandarin, Cleopatra mandarin x Swingle citrumelo hybrid, Carrizo citrange, C-35 citrange and Marumi kumquat were moderate tolerant; Volkameriana, Swingle citrumelo, Pomeroy trifoliate and Sarawak bintangor were sensitive; and a local trifoliate was found to be the most sensitive to iron chlorosis in a high $\mathrm{pH}$ medium.
\end{abstract}

Index terms: rootstock, iron deficiency, leaf chlorophyll concentration.

\section{Resposta de porta-enxerto de Citrus a deficiência de ferro sob condições de alto pH}

\section{RESUMO}

A Turquia é um dos principais países produtores de cítricos da Bacia do Mediterrâneo. Aproximadamente $90 \%$ da produção total de citros na Turquia é realizada na região do Mediterrâneo. O solo da região do Mediterrâneo é calcário e devido a laranja azeda ser tolerante a condições de alto $\mathrm{pH}$, estes porta-enxertos são amplamente utilizados nesta região. O porta-enxertos de laranja azeda, no qual é se adapta bem aos solos calcários, tem efeitos positivos sobre o rendimento e a qualidade de frutos, mas é extremamente sensível à doença do vírus da tristeza dos citros. Como a laranja azeda é muito sensível à tristeza, é necessário encontrar um porta-enxerto alternativo que seja bem adaptado aos solos calcários e que tenha bons rendimentos e qualidade dos frutos. Para este fim, 16 porta-enxertos e genótipos de citros que poderiam ser usados como porta-enxertos, foram testados em condições de $\mathrm{pH}$ elevado para clorose causada pela deficiência de ferro em câmara de crescimento. No final deste experimento, as laranjas azedas Tuzcu 891 e Gou Tou e a

\footnotetext{
${ }^{1}$ Department of Horticulture, Faculty of Agriculture, Cukurova University, Adana, Turkey

Corresponding author: Berken Cimen, Cukurova University, Faculty of Agriculture, Department of Horticulture, 01330, Adana, Turkey.E-mail: bcimen@cu.edu.tr
} 
tangerina Antalya Cleopatra foram os mais tolerantes; pomelo Duncan, laranja azeda Tuzcu 31-31, tangerina Sunki, tangerina Nasnaran, hibrido entre tangerina Cleopatra x citrumelo Swingle, citrange Carrizo, citrange C-35 e kumquat Marumi foram moderadamente tolerantes; Volkameriano, citrumelo Swingle, trifoliata Pomeroy e tangor Sarawak foram sensíveis; e um trifoliata local foi considerado o mais sensível à clorose de ferro em um meio de $\mathrm{pH}$ elevado.

Termos de indexação: porta-enxerto, deficiência de ferro, concentração de clorofila.

\section{INTRODUCTION}

World citrus production was 128,922,136 tons in 2011. Due to the steady increase in citrus production in Turkey, $3,613,770$ million tons of citrus fruits were produced in 2011. From the total of citrus fruits produced in Turkey, $1,730,150$ tons were oranges, 872,251 tons were mandarins, 790,211 tons were lemons and 218,988 were grapefruit (FAO, 2015). Citrus production and consumption have been increasing strongly in Turkey, because of the suitable ecological conditions for fruit quality of the Mediterranean region of Turkey.

Mediterranean countries have a suitable climate for citrus but it is estimated that from 20 to $50 \%$ of fruit trees grown in the Mediterranean basin suffer from iron (Fe) deficiency. The most prevalent cause of Fe deficiency in this region is the presence of high levels of carbonate ions in the calcareous soils (Pestana et al., 2005). Such soils contain high bicarbonate $\left(\mathrm{HCO}_{3}^{-}\right)$concentrations in their soil solution, which are characterized by a high $\mathrm{pH}$ (Mengel, 1994). These soils often have more than $20 \%$ of calcium and magnesium carbonates and are strongly buffered, with $\mathrm{pH}$ between 7.5 and 8.5 (Pestana et al., 2005). Fe uptake is highly dependent on soil $\mathrm{pH}$ and iron activity in solution decreases 1000 -fold for each $\mathrm{pH}$ unit rise to reach a minimum within the range from 7.4 to 8.5 (Byrne et al., 1995).

Fe is an essential element for all living organisms. It is required by many functional molecules involved in a great variety of metabolic pathways, such as nitrogen fixation, ribonucleotide reduction, electron transfer, activation and transport of oxygen, as well as inactivation of reduced forms of oxygen (Eisenstein \& Blemings, 1998; Zocchi et al., 2007).

Citrus is sensitive to iron chlorosis, in which is a common nutritional problem in high $\mathrm{pH}$ soil conditions (Chouliaras et al., 2004). Sour orange rootstock is well adapted to calcerous and other soil types and is used widely in the Mediterranean basin (Özsan, 1979). Trees grafted onto sour orange produce excellent quality fruit, but are susceptible to Citrus Tristeza Virus (CTV), a very serious disease that is insect-transmitted. Sour orange rootstock is used in $96 \%$ of the Turkish citrus growing area. If this disease comes to Turkey, the citrus growing areas could be destroyed. Although existing trifoliate orange and their hybrids are tolerant to CTV, these rootstocks may cause several microelement deficiencies in high $\mathrm{pH}$ soils, especially for Fe.

The present study evaluated 16 citrus genotypes used as rootstocks in citriculture in order to determine the tolerance levels to lime induced iron deficiency under controlled conditios. The tolerance levels were assessed by plant growth, leaf chrolophyll concentration and leaf total and active iron concentrations.

\section{MATERIAL AND METHODS}

\section{Plant material and experiment conditions}

Sixteen citrus genotypes studied in this experiment: Tuzcu 31-31 sour orange (Citrus aurantium L.), Tuzcu 891 sour orange (Citrus aurantium L.), Gou Tou sour orange (Citrus aurantium L. var. Gou Tou), Volkameriana (Citrus volkameriana V. Ten. \& Pasq), Duncan grapefruit (Citrus paradisi Macf.), Sunki mandarin [Citrus sunki (Hayata) hort. ex Tanaka], Cleopatra mandarin (Citrus reshni Tan.), Nasnaran (Citrus amblycarpa Ochse), Sarawak bintangor (Citrus reticulata Blanco x Citrus aurantium L.), Marumi kumquat (Fortunella japonica), Swingle citrumelo (Citrus paradisi Macf. var. Duncan x Poncirus trifoliata (L.) Raf), Cleopatra mandarin x Swingle citrumelo hybrid [(Citrus reshni Tan.,) x (Citrus paradisi Macf. x Poncirus trifoliate var. Duncan Raf.], Carrizo citrange [Citrus sinensis (L.) Osb. x Poncirus trifoliata (L.) Raf.], C-35 citrange [Poncirus trifoliata (L.) Raf. x Citrus sinensis. Osb. Ruby], Pomeroy trifoliate (Poncirus trifoliata var. Pomeroy) and a local trifoliate (Poncirus trifoliata). Seeds were obtained from Cukurova University, Faculty of Agriculture 'Tuzcu Citrus Collection' and 'France Citrus Collection' (Agricultural Research Station, SRA; Institut National de la Recherche Agronomique, INRA).

Seeds were germinated in the dark at $22{ }^{\circ} \mathrm{C}$ in plastic trays with sterilised peat. After germination, the seedlings were grown in peat for eight weeks in a greenhouse 
with day/night temperatures of $26 / 22^{\circ} \mathrm{C}$, and a relative humidity of $65 \%$. After eight weeks, uniform seedlings were transferred in quartz sand in a growth chamber and plant fresh weight, plant height and leaf numbers were recorded.

After transplantation of the plants to quartz sand all plants were irrigated with a solution of the following composition for 8 months: $1.25 \mathrm{mM} \mathrm{KNO}_{3}, 0.625 \mathrm{mM} \mathrm{KH}_{2} \mathrm{PO}_{4}$, $2.00 \mathrm{mM} \mathrm{MgSO}_{4}, 2.00 \mathrm{mM} \mathrm{Ca}\left(\mathrm{NO}_{3}\right)_{2}$, EDTA-Fe $(125 \mu \mathrm{M})$, $25.0 \mu \mathrm{M} \mathrm{H}_{3} \mathrm{BO}_{3}, 2.00 \mu \mathrm{M} \mathrm{MnSO}_{4}, 2.00 \mu \mathrm{M} \mathrm{ZnSO}_{4}$, $0.50 \mu \mathrm{M} \mathrm{CuSO}_{4}, 0.065 \mu \mathrm{M}\left(\mathrm{NH}_{4}\right)_{6} \mathrm{Mo}_{7} \mathrm{O}_{24}$. The $\mathrm{pH}$ and $\mathrm{EC}$ of the final solution were adjusted to 5.8 and $1.05 \mathrm{mS}$ respectively. Due to the size of the seedlings in the begining of the experiment, half-strength solutions were used during the first three months. After this period, the solutions were then replaced with full strength solutions. Stress application was started 11 months after plants were transplanted to quartz sand.

In order to provide Fe deprived conditions [(-)Fe treatment], the solution was adjusted to $\mathrm{pH} 7.8 \pm 0.1$ by adding $2 \mathrm{~g} \mathrm{~L}^{-1} \mathrm{CaCO}_{3}+3 \mathrm{mM} \mathrm{NaHCO}_{3}$ to the nutrient soluiton and $10^{-5} \mathrm{MFe}$ was added $(\mathrm{EC}=0.967)$. For control plants $10^{-4} \mathrm{M}$ Fe EDTA was added to the nutrient solution and the $\mathrm{pH}$ of the control nutrient was adjusted to $6.0 \pm 0.1$. Control and (-)Fe treatment were imposed for four months.

The experiment was carried out in a growth chamber. Growth chamber conditions included a relative humidity $65 \%$, the photosynthetic photon flux (PPF) at the top of the plant canopy (approximately $20 \mathrm{~cm}$ above the plants) averaged $300 \pm 25 \mu \mathrm{mol} \mathrm{m}^{-2} \mathrm{~s}^{-1}$ and was provided by cool white fluorescent lamps. Light period was $16 / 8 \mathrm{~h}$ with a $26^{\circ} \mathrm{C}$ day and $20^{\circ} \mathrm{C}$ night. The experiment was arranged as in a complete randomized design, 6 replications, and 5 plants in each replication. A total of 30 plants were used in both control and (-)Fe treatments for each genotype.

\section{Iron chlorosis scale}

The seedlings were rated for chlorosis based on their fully expanded new leaves as follows: $1=$ healthy green leaves; $2=$ yellowish-green interveinal areas, green veins; $3=$ greenish-yellow interveinal areas, green veins; $4=$ yellow interveinal areas, green veins; $5=$ yellow-white interveinal areas, pale green veins, some defolation (Byrne et al., 1995).

\section{Indirect leaf chlorophyll concentration}

Indirect leaf chlorophyll (Chl) concentration was estimated using a portable SPAD-502 meter (Minolta, Osaka, Japan) as SPAD readings. Readings were taken on the two youngest fully expanded leaves of each plant. SPAD readings were used to estimate leaf $\mathrm{Chl}$ concentration because there is a strong relationship between SPAD readings and $\mathrm{Chl}$ levels in citrus leaves (Jifon et al., 2005).

\section{Total and active iron concentrations}

At the end of the experiment, for total Fe concentration, fully expanded leaves were ground, ashed at $550{ }^{\circ} \mathrm{C}$ and digested in acid solution $(3.3 \% \mathrm{HCl}, \mathrm{v} / \mathrm{v})$. For active $\mathrm{Fe}$ concentration, leaves were ground and shaked in $1 \mathrm{~N} \mathrm{HCl}$ extraction solution $(1: 10, \mathrm{v} / \mathrm{v})$ for two hours. The total and active concentrations of $\mathrm{Fe}$ in leaves were determined by ICP (Inductively-Coupled Plasma, PerkinElmer, Optima 7000 DV).

\section{Statistical analysis}

The experiment was arranged as a complete randomized design and the data were subjected to ANOVA. Significant differences between means were evaluated by using Tukey's multiple range test at $P \leq 0.01$. Also control and (-)Fe treatment were compared using "Student's $t$ test". All statistical analyses were performed by using SAS v9.00 software.

\section{RESULTS}

\section{Plant growth}

Leaf number was significantly affected by high $\mathrm{pH}$, plants grown in high $\mathrm{pH}$ conditions were lighter and with fewer leaves. The local trifoliate was determined to be the most affected genotype for iron chlorosis, whereas Gou Tou sour orange, Tuzcu 891 sour orange and Antalya Cleopatra mandarin were the least affected regarding leaf number observations. Control and (-)Fe treatments of Tuzcu 31-31 sour orange, Nasnaran mandarin, Swingle citrumelo, Carrizo citrange, Pomeroy trifoliate and the local trifoliate genotypes were significantly different according to a t-test performed (Table 1). 
Table 1. Leaf number of genotypes under Fe deprived conditions

\begin{tabular}{lllc}
\hline \multicolumn{1}{c}{ Genotype } & \multicolumn{1}{c}{ Control } & $(-) \mathrm{Fe}$ & t test \\
\hline Tuzcu 31 31 sour orange & $31.10 \mathrm{ef}^{(1)} \mathrm{A}^{(2)}$ & $23.25 \mathrm{e} \mathrm{B}$ & $*$ \\
Tuzcu 891 sour orange & $32.47 \mathrm{ef}$ & $31.50 \mathrm{cde}$ & n.s. \\
Gou tou sour orange & $49.40 \mathrm{bcd}$ & $48.40 \mathrm{a}$ & n.s. \\
Volkameriana & $37.10 \mathrm{cdef}$ & $31.50 \mathrm{cde}$ & n.s. \\
Sunki mandarin & $45.00 \mathrm{bcde}$ & $40.89 \mathrm{abc}$ & n.s. \\
Cleopatra mandarin & $51.80 \mathrm{abc}$ & $48.66 \mathrm{a}$ & n.s. \\
Nasnaran mandarin & $58.30 \mathrm{ab} \mathrm{A}$ & $39.80 \mathrm{abcd} \mathrm{B}$ & $*$ \\
Swingle citrumelo & $64.70 \mathrm{a} \mathrm{A}$ & $47.90 \mathrm{ab} \mathrm{B}$ & $*$ \\
C X S & $40.20 \mathrm{cdef}$ & $36.11 \mathrm{~cd}$ & n.s. \\
Carrizo citrange & $52.25 \mathrm{abc} \mathrm{A}$ & $42.44 \mathrm{abc} \mathrm{B}$ & $*$ \\
Pomeroy trifoliate & $40.10 \mathrm{cdef} \mathrm{A}$ & $32.80 \mathrm{cde} \mathrm{B}$ & $*$ \\
C-35 citrange & $45.57 \mathrm{bcde}$ & $40.40 \mathrm{abc}$ & n.s. \\
Marumi kumquat & $33.56 \mathrm{ef}$ & $28.30 \mathrm{de}$ & n.s. \\
Sarawak bintangor & $29.30 \mathrm{f}$ & $23.80 \mathrm{e}$ & n.s. \\
Duncan grapefruit & $39.42 \mathrm{cdef}$ & $36.50 \mathrm{bcd}$ & n.s. \\
Local trifoliate & $34.45 \mathrm{def} \mathrm{A}$ & $22.90 \mathrm{e} \mathrm{B}$ & $*$ \\
Significance & $* 3)$ & 11.69 & - \\
D (0.01) & $* *$ & 15.25 & - \\
\hline
\end{tabular}

${ }^{(1)}$ Means followed by different letters in the same column are significantly different (Tukey's multiple range test, $\alpha=0.01$ ); ${ }^{(2)}$ Means followed by different letters in the same row are significantly different (Student's $t$ test, $\mathrm{P} \leq 0.05$ ); ${ }^{(3)} \mathrm{n}$.s.: not significant; $* * \mathrm{P} \leq 0.01 ; * \mathrm{P} \leq 0.05$.

All genotypes in this experiment resulted as a significant decrease in plant height under Fe deprived conditions and the greatest decline was observed in Swingle citrumelo and the local trifoliate (Table 2). Gou Tou sour orange was determined to be the most tolerant genotype, in terms of plant height (Table 2 In the student test we compared the effect of iron chlorosis between control and (-)Fe treatment. According to a $t$ test, significant differences were not determinted in plant height between control and (-)Fe treatments in Tuzcu 891 sour orange, Gou Tou sour orange, Sunki mandarin, Carrizo citrange, C-35 citrange and Duncan grapefruit. The other genotypes were grouped differently (Table 2).

In terms of plant fresh weight under Fe deprived conditions, more weight loss was observed in local trifoliate, Tuzcu 31-31 sour orange, Nasnaran mandarin and Volkameriana; whereas less weight loss was observed in Antalya Cleopatra mandarin and Sunki mandarin (Table 3). In this experiment Tuzcu 31-31, Tuzcu 891 and Gou Tou sour oranges showed different responses to $\mathrm{Fe}$ chlorosis. Tuzcu 31-31 sour orange had fewer leaves, shorter plant height and lower plant weight than Tuzcu 891 and Gou Tou sour oranges. Tuzcu 31-31 sour orange, Volkameriana, Nasnaran mandarin, Swingle citrumelo and
Local trifoliate genotypes showed significant differences comparing the control plants and those under high $\mathrm{pH}$. $\mathrm{Fe}$ chlorosis affected these genotypes with lower plant fresh weight (Table 3).

\section{Leaf chlorophyll concentrations and iron chlorosis scale}

The most obvious symptom of Fe deficiency in plants is commonly called iron chlorosis. At the beginning of the experiment, the plants had no visual symptoms of iron deficiency. The high $\mathrm{pH}$ treatment created characteristic visual symptoms of Fe chlorosis after 30 days on local trifoliate firstly. At the end of the experiment extremely chlorotic leaves were observed on local trifoliate and Pomeroy trifoliate, whereas the healthiest green leaves were determined on Tuzcu 891 sour orange in the high $\mathrm{pH}$ treatment. In the student test, except for Tuzcu 891 sour orange, all genotypes showed significant differences (Table 4). The SPAD measurements were used as an estimate of leaf $\mathrm{Chl}$ concentration, because there is a positive linear relationship between these two parameters $\left(r^{2}>0.8\right.$, Jifon et al., 2005). Leaves of local trifoliate 
Table 2. Plant height $\left(\mathrm{cm} \mathrm{plant}^{-1}\right)$ of genotypes under Fe deprived conditions

\begin{tabular}{|c|c|c|c|}
\hline Genotype & Control & $(-) \mathrm{Fe}$ & t test \\
\hline Tuzcu 3131 sour orange & $50.15 \mathrm{efgh}^{(1)} \mathrm{A}^{(2)}$ & 33.36 efgB & $*$ \\
\hline Tuzcu 891 sour orange & $55.37 \mathrm{defg}$ & $51.40 \mathrm{cde}$ & n.s. \\
\hline Gou tou sour orange & 48.20 efg & $47.95 \mathrm{cdef}$ & n.s. \\
\hline Volkameriana & $88.20 \mathrm{ab} \mathrm{A}$ & $60.30 \mathrm{bcd} \mathrm{B}$ & $*$ \\
\hline Sunki mandarin & 53.65 defg & $50.30 \mathrm{cdef}$ & n.s. \\
\hline Cleopatra mandarin & 58.67 defg A & 46.05 defg B & $*$ \\
\hline Nasnaran mandarin & $46.50 \mathrm{fg} \mathrm{A}$ & 29.75 fg B & $*$ \\
\hline Swingle citrumelo & $86.80 \mathrm{abc} A$ & 49.77 cdef B & $*$ \\
\hline $\mathrm{CX} \mathrm{S}$ & $64.45 \operatorname{cdef} A$ & 52.30 cde B & $*$ \\
\hline Carrizo citrange & $106.05 \mathrm{a}$ & $97.13 \mathrm{a}$ & n.s. \\
\hline Pomeroy trifoliate & $91.97 \mathrm{ab} \mathrm{A}$ & $78.00 \mathrm{ab} \mathrm{B}$ & $*$ \\
\hline C-35 citrange & 70.57 bcde & $68.40 \mathrm{bc}$ & n.s. \\
\hline Marumi kumquat & $36.95 \mathrm{~g} \mathrm{~A}$ & $25.40 \mathrm{~g} \mathrm{~B}$ & $*$ \\
\hline Sarawak bintangor & $41.90 \mathrm{fg} \mathrm{A}$ & $29.25 \mathrm{fg} \mathrm{B}$ & $*$ \\
\hline Duncan grapefruit & $46.60 \mathrm{fg}$ & 37.22 efg & n.s. \\
\hline Local trifoliate & $75.85 \mathrm{bcd} A$ & 47.05 cdef B & $*$ \\
\hline Significance ${ }^{(3)}$ & $* *$ & $* *$ & - \\
\hline$D(0.01)$ & 22.84 & 21.42 & - \\
\hline
\end{tabular}

${ }^{(1)}$ Means followed by different letters in the same column are significantly different (Tukey's multiple range test, $\alpha=0.01$ ); ${ }^{(2)}$ Means followed by different letters in the same row are significantly different (Student's $t$ test, $P \leq 0.05$ ); ${ }^{(3)}$ n.s.: not significant; $* * P \leq 0.01 ; * P \leq 0.05$.

Table 3. Plant fresh weight $\left(\mathrm{g}\right.$ plant $\left.{ }^{-1}\right)$ of genotypes under Fe deprived conditions

\begin{tabular}{|c|c|c|c|}
\hline Genotype & Control & $(-) \mathrm{Fe}$ & t test \\
\hline Tuzcu 3131 sour orange & $34.68 \mathrm{a}-\mathrm{d}^{(1)} \mathrm{A}^{(2)}$ & $17.68 \mathrm{c}-\mathrm{fB}$ & $*$ \\
\hline Tuzcu 891 sour orange & $46.15 \mathrm{a}$ & $39.04 \mathrm{a}$ & n.s. \\
\hline Gou tou sour orange & $40.68 \mathrm{abc}$ & $35.95 \mathrm{ab}$ & n.s.. \\
\hline Volkameriana & $45.93 \mathrm{ab} \mathrm{A}$ & $26.05 \mathrm{bcd} \mathrm{B}$ & $*$ \\
\hline Sunki mandarin & 29.87 bcde & $26.91 \mathrm{abc}$ & n.s. \\
\hline Cleopatra mandarin & $26.32 \mathrm{c}-\mathrm{f}$ & $24.29 \mathrm{bcd}$ & n.s. \\
\hline Nasnaran mandarin & $26.81 \mathrm{c}-\mathrm{fA}$ & 14.16 def B & $*$ \\
\hline Swingle citrumelo & $37.87 \mathrm{a}-\mathrm{d} \mathrm{A}$ & 24.46 bcd B & $*$ \\
\hline $\mathrm{CXS}$ & 22.46 def & 20.14 cde & n.s. \\
\hline Carrizo citrange & $41.17 \mathrm{abc}$ & $36.19 \mathrm{ab}$ & n.s. \\
\hline Pomeroy trifoliate & 22.47 def & $18.38 \mathrm{cdef}$ & n.s. \\
\hline C-35 citrange & 30.77 a-e & $26.52 \mathrm{bcd}$ & n.s. \\
\hline Marumi kumquat & $10.99 \mathrm{f}$ & $7.05 \mathrm{f}$ & n.s. \\
\hline Sarawak bintangor & $12.49 \mathrm{f}$ & 9.37 ef & n.s. \\
\hline Duncan grapefruit & 29.20 cde & $23.80 \mathrm{bcd}$ & n.s. \\
\hline Local trifoliate & 15.47 ef $\mathrm{A}$ & $6.32 \mathrm{fB}$ & $*$ \\
\hline Significance ${ }^{(3)}$ & $* *$ & $* *$ & - \\
\hline$D(0.01)$ & 16.18 & 12.48 & - \\
\hline
\end{tabular}

${ }^{(1)}$ Means followed by different letters in the same column are significantly different (Tukey's multiple range test, $\alpha=0.01$ ); ${ }^{(2)}$ Means followed by different letters in the same row are significantly different (Student's t test, $P \leq 0.05$ ); ${ }^{(3)}$ n.s.: not significant. $* * P \leq 0.01 ; * P \leq 0.05$. 
Table 4. Iron chlorosis scale ${ }^{(4)}$ of genotypes under Fe deprived conditions

\begin{tabular}{llll}
\hline \multicolumn{1}{c}{ Genotype } & Control & $(-) \mathrm{Fe}$ & t test \\
\hline Tuzcu 31 31 sour orange & 1.00 & $1.05 \mathrm{f}(1)$ & $n . s$. \\
Tuzcu 891 sour orange & 1.00 & $1.20 \mathrm{f}$ & $n . s$. \\
Gou tou sour orange & 1.00 & $1.06 \mathrm{f}$ & $n . s$. \\
Volkameriana & $1.00 \mathrm{~B}(2)$ & $2.40 \mathrm{cde} \mathrm{A}$ & $*$ \\
Sunki mandarin & $1.00 \mathrm{~B}$ & $2.00 \mathrm{def} \mathrm{A}$ & $*$ \\
Cleopatra mandarin & $1.00 \mathrm{~B}$ & $1.80 \mathrm{ef} \mathrm{A}$ & $*$ \\
Nasnaran mandarin & $1.00 \mathrm{~B}$ & $1.70 \mathrm{ef} \mathrm{A}$ & $*$ \\
Swingle citrumelo & $1.00 \mathrm{~B}$ & $3.20 \mathrm{bc} \mathrm{A}$ & $*$ \\
C X S & $1.00 \mathrm{~B}$ & $1.83 \mathrm{ef} \mathrm{A}$ & $*$ \\
Carrizo citrange & $1.00 \mathrm{~B}$ & $2.00 \mathrm{def} \mathrm{A}$ & $*$ \\
Pomeroy trifoliate & $1.00 \mathrm{~B}$ & $4.00 \mathrm{ab} \mathrm{A}$ & $*$ \\
C-35 citrange & $1.00 \mathrm{~B}$ & $2.20 \mathrm{cdef} \mathrm{A}$ & $*$ \\
Marumi kumquat & $1.00 \mathrm{~B}$ & $3.00 \mathrm{bcd} \mathrm{A}$ & $*$ \\
Sarawak bintangor & $1.00 \mathrm{~B}$ & $2.66 \mathrm{cde} \mathrm{A}$ & $*$ \\
Duncan grapefruit & $1.00 \mathrm{~B}$ & $2.57 \mathrm{cde} \mathrm{A}$ & $*$ \\
Local trifoliate & $1.00 \mathrm{~B}$ & $5.00 \mathrm{a} \mathrm{A}$ & - \\
Significance(3) & Ö.D. & $* *$ & - \\
D (0.01) & - & 1.15 & $*$ \\
\hline
\end{tabular}

${ }^{(1)}$ Means followed by different letters in the same column are significantly different (Tukey's multiple range test, $\alpha=0.01$ ); ${ }^{(2)}$ Means followed by different letters in the same row are significantly different (Student's $t$ test, $P \leq 0.05$ ); ${ }^{(3)} \mathrm{n}$.s.: not significant; ${ }^{*} P \leq 0.01 ; * P \leq 0.05 ;{ }^{(4)}$ Scale values; $1=$ healthy gren leaves; $2=$ yellowish-green interveinal areas, green veins; $3=$ greenishyellow interveinal areas, green veins; $4=$ yellow interveinal areas, green veins; $5=$ yellow-white interveinal areas, palegreen veins, some defolation (Byrne et al.,1995).

had the lowest Chl concentration followed by Pomeroy trifoliate and Swingle citrumelo, while leaves of Tuzcu 31-31, Gou Tou and Tuzcu 891 sour oranges had the highest $\mathrm{Chl}$ concentration. In addition, leaf $\mathrm{Chl}$ concentrations of leaves of Tuzcu 31-31, Gou Tou and Tuzcu 891 sour oranges were not significantly different according to t-tests (Table 5).

\section{Total and active iron concentrations}

In general, the greatest decreases in terms of total and active $\mathrm{Fe}$ concentrations were observed in the 'Local trifoliate' plants whereas the lowest were observed in the Tuzcu 31-31 sour orange plants. Sarawak bintangor and Pomeroy trifoliate also showed decreases in both leaf total and active Fe concentrations. The highest decrease in terms of active iron concentration were observed respectively on 'local trifoliate' and Sarawak bintangor plants, the lowest on Marumi kumquat and Tuzcu 31-31 sour orange. Comparing the control plants and those under high $\mathrm{pH}$, except for Tuzcu 31-31 sour orange, Marumi kumquat and Duncan grapefruit, all genotypes showed significant differences (Figure 1).

\section{DISCUSSION}

For growth parameters, the number of leaves, plant height and plant fresh weight were the most affected by the high $\mathrm{pH}$ treatment. Previous studies also claim that bicarbonate ions hamper the development of plant (Mengel, 1994; Sabir et al., 2010; Cimen et al., 2014). The growth responses of the genotypes to iron chlorosis were different from each other. In terms of growth parameters, Tuzcu 891 and Gou Tou sour oranges were least affected under Fe deprived conditions, whereas Swingle citrumelo and Local trifoliate were the most.

However, these growth parameters may not be sufficient to evaluate tolerance to Fe chlorosis of citrus rootstocks (Pestana et al., 2005). Several authors have classified Fe tolerance of citrus rootstocks supported on growth and chlorosis parameters of shoots (Hamzé et al., 1986; Sudahono et al., 1994; Byrne et al., 1995). They considered 
Table 5. SPAD readings of genotypes under Fe deprived conditions

\begin{tabular}{|c|c|c|c|}
\hline Genotype & Control & $(-) \mathrm{Fe}$ & t test \\
\hline Tuzcu 3131 sour orange & $66.68 \mathrm{a}^{(1)} \mathrm{A}^{(2)}$ & 52.37 a B & $*$ \\
\hline Tuzcu 891 sour orange & $48.92 \mathrm{de}$ & $46.09 \mathrm{ab}$ & n.s. \\
\hline Gou tou sour orange & 53.13 bcde A & $43.46 \mathrm{abc} B$ & $*$ \\
\hline Volkameriana & 50.92 cde A & $31.72 \mathrm{de} \mathrm{B}$ & $*$ \\
\hline Sunki mandarin & 48.59 de A & $38.03 \mathrm{bcd} \mathrm{B}$ & $*$ \\
\hline Cleopatra mandarin & 65.42 a A & 52.74 a B & $*$ \\
\hline Nasnaran mandarin & 43.39 e $\mathrm{A}$ & $38.13 \mathrm{bcd} \mathrm{B}$ & $*$ \\
\hline Swingle citrumelo & $64.28 \mathrm{a} \mathrm{A}$ & $35.24 \mathrm{~cd} \mathrm{~B}$ & $*$ \\
\hline $\mathrm{CXS}$ & $66.57 \mathrm{a} \mathrm{A}$ & $45.80 \mathrm{ab} \mathrm{B}$ & $*$ \\
\hline Carrizo citrange & $61.45 \mathrm{ab} A$ & $46.65 \mathrm{ab} B$ & $*$ \\
\hline Pomeroy trifoliate & 65.56 a A & 23.87 e B & $*$ \\
\hline C-35 citrange & $60.23 \mathrm{abc} \mathrm{A}$ & $37.94 \mathrm{bcd} \mathrm{B}$ & $*$ \\
\hline Marumi kumquat & 64.42 a A & $48.27 \mathrm{ab} B$ & $*$ \\
\hline Sarawak bintangor & $59.14 \mathrm{abc} \mathrm{A}$ & 31.37 de B & $*$ \\
\hline Duncan grapefruit & $61.25 \mathrm{ab} A$ & 49.13 a B & $*$ \\
\hline Local trifoliate & $58.10 \mathrm{abcd} A$ & $10.73 \mathrm{f} \mathrm{B}$ & $*$ \\
\hline Significance ${ }^{(3)}$ & $* *$ & $* *$ & - \\
\hline$D(0.01)$ & 10.07 & 10.52 & - \\
\hline
\end{tabular}

${ }^{(1)}$ Means followed by different letters in the same column are significantly different (Tukey's multiple range test, $\alpha=0.01$ ); ${ }^{(2)}$ Means followed by different letters in the same row are significantly different (Student's $t$ test, $P \leq 0.05$ ); ${ }^{(3)}$ n.s.: not significant; $* * P \leq 0.01 ; * P \leq 0.05$.
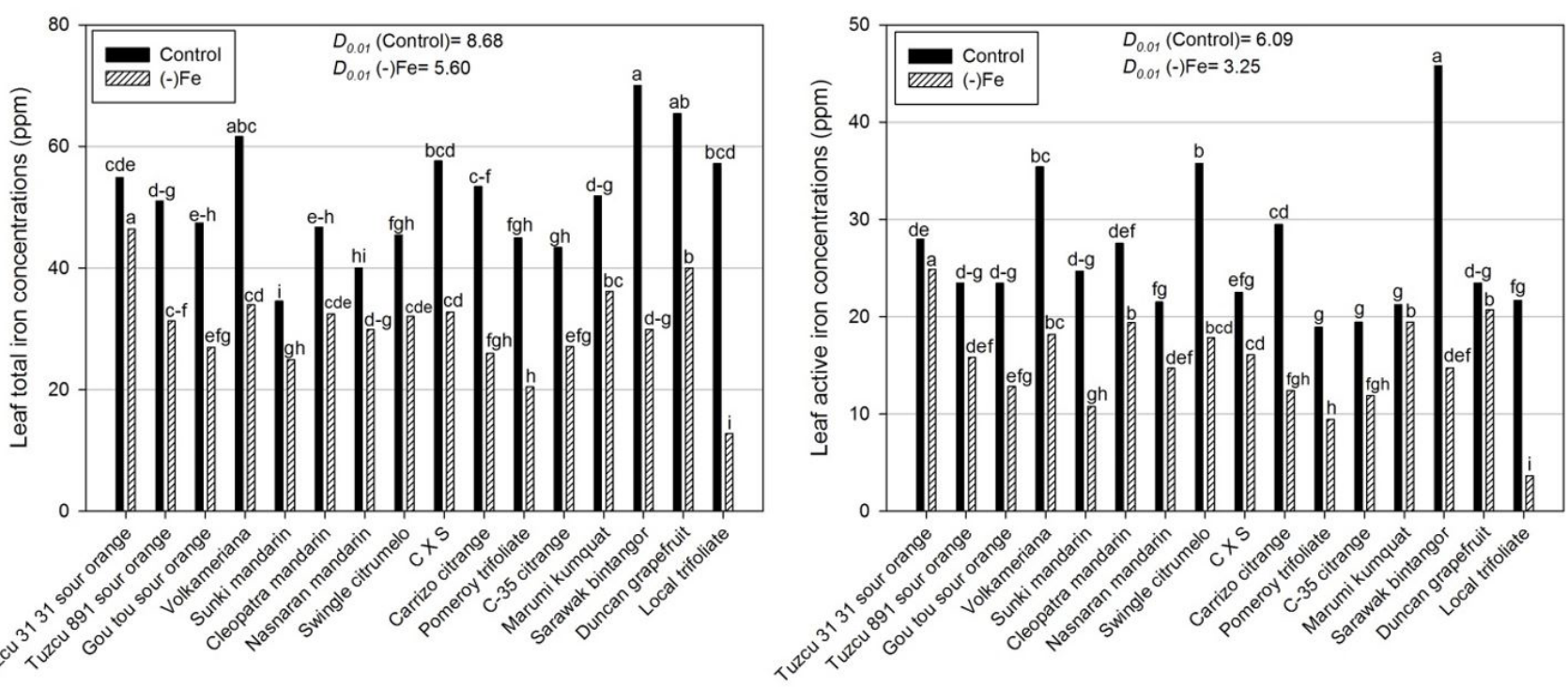

Figure 1. Total and active iron concentrations (ppm) of genotypes under Fe deprived conditions. Data represent the results of a one way ANOVA in each treatment. Significant differences between genotypes were evaluated by using Tukey's multiple range test at $P \leq 0.01$.

that volkameriana, and sour orange plants were tolerant; Taiwanica and Carrizo citrange less tolerant to Fe chlorosis, whereas the Volkameriana rootstocks were more sensitive.
Previous studies that examined the responses of citrus rootstocks to iron chlorosis, SPAD and total Chl content showed a significant reduction when rootstocks were 
exposed to $\mathrm{Fe}$ deprived conditions (Byrne et al., 1995; Pestana et al., 2001; Pestana et al., 2005; Castle \& Nunnallee, 2009). The values of chlorophyll may give information not only about the degree of chlorosis but also about the differential behaviour of genotypes to Fe chlorosis. The most evident effect of Fe chlorosis is a decrease in photosynthetic pigments, resulting in a relative enrichment of carotenoids over chlorophylls, and producing yellow, chlorotic leaves. The loss of pigmentation is caused by decreased chlorophyll content in chloroplasts. This negatively affects the rate of photosynthesis and, therefore, the development of biomass. Fe deficiency affects the physiology and biochemistry of the whole plant, as $\mathrm{Fe}$ is an important cofactor of many enzymes, including those involved in the biosynthetic pathway of chlorophylls. Under Fe deprived conditions, sour oranges maintained significantly greater $\mathrm{Fe}$ and chlorophyll contents compared with local trifoliate. The ability of sour orange rootstocks to maintain high leaf $\mathrm{Fe}$ and chlorophyll concentrations under Fe deprived conditions have been documented previously (Sudahono et al., 1994; Pestana et al., 2005; Cimen et al., 2014). Iron chlorosis scale observations were used in previous citrus studies. Researchers considered that trifoliates exhibit severe chlorosis than other rootstocks. Carrizo and Troyer citranges had a similar middle degree of tolerance to $\mathrm{Fe}$ chlorosis. Also they indicated that the rootstocks that showed few or no chlorosis symptoms are sour oranges and Cleopatra mandarin (Maxwell \& Wutscher, 1976; Hamzé et al., 1986; Sudahono et al., 1994; Byrne et al., 1995; Ferrarezi et al., 2007; Castle \& Nunnallee, 2009). In the present study SPAD readings were used in order to compare leaf $\mathrm{Chl}$ concentrations of the leaves of rootstocks under control and (-)Fe treatments. Yellow interveinal areas and green veins symptoms on leaves of Pomeroy and local trifoliate orange were determined whereas Tuzcu 891 sour orange, Nasnaran mandarin and Gou Tou sour orange had healty green leaves.

Results from SPAD readings and iron chlorosis scale observations were in agreement with each other. It seems that Tuzcu 3131 and Gou Tou sour oranges maintained significantly greater chlorophyll contents in comparison to local trifoliate and Pomeroy trifoliate. The data obtained in the present study agrees with the results from other authors (Hamzé et al., 1986; Sudahono et al., 1994).

In previous studies, researchers claim that total iron concentration of leaves decreased depending on the severity of the lime induced Fe chlorosis (Chouliaras et al., 2004; Torres et al., 2006), but some studies reported that there is no relationship between these two parameters or an existing relationship is not linear. For this reason, it was claimed that chlorotic leaves can contain high total iron concentration and that these chlorotic leaves can not be used to diagnosis iron deficiency (Razeto, 1982; Hurley et al., 1986; Sudahono et al., 1994; Mohammad et al., 1998; Abadia et al., 2000; Razeto \& Valdes, 2006; Ferrarezi et al., 2007). In addition, the iron paradox was not experienced under controlled conditions (Morales et al., 1998). In this study, the iron paradox was not observed on the genotpyes, total iron concentration and chlorosis paralelled each other.

The majority of iron uptake of plants is as $\mathrm{Fe}^{+3}$ and $\mathrm{Fe}^{+2}$ that are the metabolically active form of $\mathrm{Fe}$ (Kacar \& Katkat, 2009). Therefore, active iron concentrations were appropriate to determine iron status of the plant and this concentration reflected plant iron status (Sudahono et al., 1994; Mohammad et al., 1998; Chouliaras et al., 2004; Torres et al., 2006; Çelik \& Katkat, 2007; Ferrarezi et al., 2007). Active iron concentrations of genotypes in the study also reflected plant's iron status just as did total iron concentrations.

In conclusions, 16 citrus genotypes were evaulated for iron chlorosis, in this study. The number of leaves, plant height and plant fresh weight were reduced for all rootstocks under Fe deprived conditions high $\mathrm{pH}$ conditions. Fe deprived plants had lower total and active iron concentration than control plants. Genotypes classified as more tolerant than others were Tuzcu 891 sour orange, Gou Tou sour orange, Antalya Cleopatra mandarin and Duncan grapefruit; Tuzcu 31-31 sour orange, Sunki mandarin, Nasnaran mandarin, Cleopatra mandarin $\mathrm{x}$ Swingle citrumelo hybrid, Carrizo citrange, C-35 citrange and Marumi kumquat as medium tolerant; Volkameriana, Swingle citrumelo, Pomeroy trifoliate and Sarawak bintangor as sensitive and local trifoliate was classified as the most sensitive.

\section{REFERENCES}

Abadia J, Tagliavini M, Grasa R, Belkhodja R, Abadía A, Sanz M, Faria EA, Tsipouridis C \& Marangoni B (2000) Using the flower Fe concentration for estimating chlorosis status in fruit tree orchards: a summary report. Journal of Plant Nutrition 23(11-12): 2023-2033. http:// dx.doi.org/10.1080/01904160009382162. 
Byrne DH, Rouse RE \& Sudahono (1995) Tolerance to citrus rootstocks to lime-induced iron chlorosis. Subtropical Plant Science 47: 7-11.

Castle WS \& Nunnallee J (2009) Screening citrus rootstocks and related selections in soil and solution culture for tolerance to low-iron stress. HortScience 44(3): 638-645.

Çelik H \& Katkat V (2007) Some parameters in relation to iron nutrition status of peach orchards. Journal of Biological and Environmental Sciences 1(3): 111-115.

Chouliaras V, Therios I, Molassiotis A \& Diamantidis $\mathrm{G}$ (2004) Iron chlorosis in grafted sweet orange (Citrus sinensis L.) plants: physioloigical and biochemical responses. Biologia Plantarum 48(1): 141-144. http:// dx.doi.org/10.1023/B:BIOP.0000024292.51938.aa.

Cimen B, Yesiloglu T, Incesu M \& Yilmaz B (2014) Growth and photosynthetic response of young 'Navelina' trees budded on to eight citrus rootstocks in response to iron deficiency. New Zealand Journal of Crop and Horticultural Science 42(3): 170-182. http://dx.doi.org/ 10.1080/01140671.2014.885064.

Eisenstein RS \& Blemings KP (1998) Iron regulatory proteins, iron responsive elements and iron homeostasis. The Journal of Nutrition 128(12): 2295-2298. PMid:9868172.

FAO - Food and Agriculture Organization of the United Nations (2015). Available from: <http://www.fao.org/>. Accessed: 18 June 2010.

Ferrarezi RS, Bataglia OC, Furlani RP \& Schammass ES (2007) Iron sources for citrus rootstock development grown on pine bark/vermiculite mixed substrate. Scientia Agricola Piracicaba Braz 64(5): 520-531. http://dx.doi. org/10.1590/S0103-90162007000500010.

Hamzé M, Ryan J \& Zaabout N (1986) Screening of citrus rootstocks for lime-induced chlorosis tolerance. Journal of Plant Nutrition 9(3): 459-469. http://dx.doi. org/10.1080/01904168609363459.

Hurley A, Walser R, Davis T \& Barney D (1986) Net photosynthesis, chlorophyll, and foliar iron in apple trees after injection with ferrous sulfate. HortScience 21: 1029-1031.

Jifon JL, Syvertsen JP \& Whaley E (2005) Growth environment and leaf anatomy affect nondestructive estimates of chlorophyll and nitrogen in Citrus sp. leaves.
Journal of the American Society for Horticultural Science 130: $152-158$.

Kacar B \& Katkat AV (2009) Plant nutrition. 4th ed. Turkey: Nobel Press. 659 p.

Maxwell NP \& Wutscher HK (1976) Yield, fruit size, and chlorosis of grapefruit on 10 rootstock. HortScience 11: 496-498.

Mengel K (1994) Iron availability in plant tissues, Iron chlorosis on calcareous soils. Plant and Soil 165(2): 275283. http://dx.doi.org/10.1007/BF00008070.

Mohammad MJ, Najim H \& Khresat S (1998) Nitric acid- and o-phenanthroline-extractable iron for diagnosis of iron chlorosis in citrus lemon trees. Communications in Soil Science and Plant Analysis 29(7-8): 1035-1043. http://dx.doi.org/10.1080/00103629809370005.

Morales F, Grasa R, Abadia A \& Abadia J (1998) Iron chlorosis paradox in fruit trees. Journal of Plant Nutrition 21(4): 815-825. http://dx.doi. org/10.1080/01904169809365444.

Özsan M (1979) Türkiye turunçgil yetiştiriciliğinin dünyadaki yeri ve önemi: akdeniz bölgesi bahçe bitkileri yetiştiriciliğinde sorunlar ve çözüm yolları ve yapılması gereken araştırmalar simpozyumu. İncekum, p. 40-46.

Pestana M, David M, Varennes A, Abadia J \& Faria EA (2001) Responses of "Newhall" orange trees to iron deficiency in hydroponics: effects on leaf chlorophyll, photosynthetic efficiency, and root ferric chelate reductase activitiy. Journal of Plant Nutrition 24(10): 1609-1620. http://dx.doi.org/10.1081/PLN-100106024.

Pestana M, Varennes A, Abadia J \& Faria EA (2005) Differential tolerance to iron deficiency of rootstocks grown in nutrient solution. Scientia 104(1): 25-36.

Razeto B (1982) Treatments for iron chlorosis in peach trees. Journal of Plant Nutrition 5(4-7): 917-922. http:// dx.doi.org/10.1080/01904168209363021.

Razeto B \& Valdes G (2006) Fruit analysis as an indicator of the iron status of nectarine and kiwi plant. HortTechnology 16(4): 579-582.

Sabir A, Bilir-Ekbiç H, Erdem H \& Tangolar S (2010) Response of four grapevine (Vitis spp.) genotypes to direct or bicarbonate-induced iron deficiency. Spanish 
Journal of Agricultural Research 8(3): 823-829. http:// dx.doi.org/10.5424/sjar/2010083-1284.

Sudahono, Byrne DH \& Rouse RE (1994) Greenhouse screening of citrus rootstocks for tolerance to bicarbonateinduced iron chlorosis. HortScience 29(2): 113-116.

Torres RM, Barra JDE, Gonzales GA, Alcaraz JR \& Leon MTC (2006) Morphological changes in leaves of Mexican lime affected by iron chlorosis. Journal of Plant Nutrition 29(4): 615-628. http://dx.doi.org/10.1080/01904160600564337.
Zocchi G, Nisi P, Dell'Orto P, Espen L \& Gallina PM (2007) Iron deficiency differently affects metabolic responses in soybean roots. Journal of Experimental Botany 58(5): 993-1000. PMid:17229758. http://dx.doi. org/10.1093/jxb/erl259.

Received: November 28, 2016 Accepted: August 18, 2017 